\title{
Neutrophil Adhesion Abnormality with Deficient Surface Membrane Proteins (gp 110 and p 98): The Effect of their Antibodies on the Function of Normal Neutrophils
}

\author{
KYOKO FUJITA, KUNIHIKO KOBAYASHI, MASASHI UCHIDA, AND TADASHI KAJII \\ Department of Pediatrics, Yamaguchi University School of Medicine, Ube, Yamaguchi, Japan 755
}

\begin{abstract}
A sister and brother previously described with neutrophil adhesion defects and a lack of two neutrophil membrane proteins, glycoprotein with a molecular weight of $110 \mathrm{~K}$ and $115 \mathrm{~K}$, were further studied. Rabbit polyclonal IgG antibodies were raised against neutrophil membrane proteins of approximately $110 \mathrm{~K}$ from normal individuals, and absorbed with the siblings' neutrophil membrane proteins. The antibodies thus absorbed reacted with two normal neutrophil membrane proteins, a $110 \mathrm{~K}$ glycoprotein and a $98 \mathrm{~K}$ protein, which were totally deficient in the siblings' neutrophils. The polyclonal antibodies were also reactive with a $95 \mathrm{~K}$ membrane protein of normal lymphocytes. The protein was missing in the siblings' lymphocytes. Three membrane proteins, Mac-1, LFA-1, and p 150, 95 each consisting of a specific $\alpha$-subunit and a $\beta$-subunit common to them, have been reported to be deficient in neutrophils from several patients with a neutrophil adhesion disease. Using monoclonal antibodies to Mac-1 $\alpha, \operatorname{LFA}-1 \alpha$, and to the $\beta$-subunit, it was deduced that the siblings' neutrophils lacked the above three membrane proteins. The disease in the siblings is thus identical with that previously described. Sodium dodecyl sulfate polyacrylamide gel electrophoresis of immunoprecipitates, formed by reacting labeled normal neutrophil membrane proteins with our polyclonal antibodies, revealed three bands, almost identical with that of immunoprecipitates formed with the anti- $\beta$-subunit monoclonal antibody. This finding indicates that the polyclonal antibodies reacted mainly with the $\beta$-subunit of the membrane proteins. The presence of the polyclonal antibodies exerted a strong inhibitory effect upon the adhesion of normal neutrophils, an intermediate effect on the chemotaxis, and to a much lesser extent on the phagocytosis. (Pediatr Res 20: 361366,1986 )
\end{abstract}

\section{Abbreviations}

gp 110, glycoprotein with a molecular weight of $110 \mathrm{~K}$ gp 115, glycoprotein with a molecular weight of $115 \mathrm{~K}$ p 98, protein with a molecular weight of $98 \mathrm{~K}$ PBS, phosphate-buffered saline

SDS-PAGE, sodium dodecyl sulfate-polyacrylamide gel electrophoresis

We have described a sister and brother who suffered from recurrent bacterial infections and whose neutrophils exhibited

Received March 22, 1985: accepted December 16, 1985.

Address for reprint requests Kyoko Fujita, Department of Pediatrics, Yamaguchi University School of Medicine, Ube, Yamaguchi, Japan 755. impaired adhesion, chemotaxis, and phagocytosis $(1,2)$. Their neutrophils lacked two membrane glycoproteins: one with a molecular weight of $110 \mathrm{~K}$ (gp 110) present on the cell surface, and the other with a molecular weight of $115 \mathrm{~K}$ (gp 115) possibly situated in the intracellular apparatuses. Their parents, both healthy, showed a reduced rate of neutrophil adhesion and reduced levels of the two glycoproteins. The disease was thus inherited in an autosomal recessive fashion. Scanning electron microscopy of the neutrophils from the brother attached on a glass surface revealed a considerable reduction of the pseudopods. On the other hand, his neutrophils in suspension were morphologically normal, a finding indicating that the cytoskeleton of the neutrophils was functionally intact (2).

Several recent reports have described a disorder similar to that in our siblings, with a deficiency of neutrophil surface proteins and impaired adhesion-dependent neutrophil functions (3-12). Anderson et al. (9) and Springer et al. (12), using monoclonal antibodies to Mac- $1 \alpha$, LFA- $1 \alpha$, and the $\beta$-subunit, demonstrated that the granulocytes in the patients with the disease lack these three components, and by implication three membrane proteins, Mac-1, LFA-1, and p150,95. Each of the three membrane proteins consists of a specific $\alpha$-subunit and $\beta$-subunit common to them.

The present study deals with 1) the preparation of rabbit polyclonal antibodies against neutrophil membrane proteins of approximately $110 \mathrm{~K}$ daltons, 2) identification of the deficiency of the $\beta$-subunit in the neutrophils and lymphocytes of the siblings, using the polyclonal antibodies, and 3 ) the study of the deleterious effects of the polyclonal antibodies on the performance of normal neutrophils. Evidence will be presented that the disease in our siblings is identical with that described by Anderson et al. (9) and Springer et al. (12).

\section{MATERIALS AND METHODS}

Cell separation. Mononuclear cells isolated from heparinized peripheral blood by Ficoll-Hypaque centrifugation were suspended in Hanks' balanced salt solution at a concentration of 1 $\times 10^{7}$ cells in $1 \mathrm{ml}$ solution. The cell suspension was placed in a Falcon plastic Petri dish, and incubated at $37^{\circ} \mathrm{C}$ in an atmosphere of $5 \% \mathrm{CO}_{2}$ and $95 \%$ air for $2 \mathrm{~h} \mathrm{(13).} \mathrm{After} \mathrm{the} \mathrm{incubation,} \mathrm{the}$ cells not attached to the Petri dish, $99 \%$ of them being lymphocytes, were collected and washed three times with PBS without metal ions, and resuspended in PBS.

Neutrophils obtained from the Ficoll-Hypaque pellet were purified by gravity sedimentation with dextran (14) and by red blood cell lysis with $0.75 \%$ ammonium chloride (15). Purified neutrophils were washed with PBS and resuspended in PBS.

Preparation of neutrophil surface proteins rich in $g p 110$. Neutrophil surface proteins from five normal adults, three men and two women, were solubilized with $0.5 \%$ Nonidet P-40 by 
the method of Arnaout et al. (6). Approximately $5 \mathrm{mg}$ of the neutrophil surface proteins were electrophoresed in a $10 \%$ polyacrylamide slab gel $(2 \mathrm{~mm}$ thick, $135 \mathrm{~mm}$ wide, and $85 \mathrm{~mm}$ long) with SDS (16). After electrophoresis, a $1-\mathrm{cm}$ wide slice was cut from the gel parallel to the electrophoretic direction and stained with Coomassie Brilliant Blue. Using the stained gel slice as a guide, a 5-mm wide strip surrounding the gp 110 band was cut out of the unstained gel block. The gel strip was cut into small pieces and immersed in $5 \mathrm{ml}$ distilled water at $4^{\circ} \mathrm{C}$ for 2 days. The extract was extensively dialyzed against $0.2 \%$ ammonium bicarbonate at $4^{\circ} \mathrm{C}$ and lyophilized. The above procedure was repeated 18 times and a total amount of $1.75 \mathrm{mg}$ of neutrophil surface proteins rich in gp 110 was collected.

Immunization procedure for the preparation of rabbit antiserum to gp 110. Forty $\mu \mathrm{g}$ of the gp 110-rich proteins prepared as described above were dissolved in $50 \mu$ l of physiologic saline, emulsified with an equal volume of Freund's complete adjuvant, and injected into the bilateral popliteal lymph nodes of a rabbit under anesthesia (17). A booster immunization of approximately $400 \mu \mathrm{g}$ of proteins was made 4 wk later by an intramuscular injection in the back. Blood was drawn from the rabbit 10 days after the second injection.

Absorption of antiserum. Surface membrane proteins were prepared from the neutrophils of the gp 110-deficient siblings (1, 2). The protein preparation, $21.2 \mathrm{mg}$, was coupled to $14 \mathrm{ml}$ of gravity-packed Sepharose $4 \mathrm{~B}$ activated with cyanogen bromide as described elsewhere (18). The rabbit antiserum was repeatedly passed through a Sepharose 4B column coupled with the surface proteins from the siblings' neutrophils to eliminate antibodies common to both normal and siblings' neutrophil surface proteins. The antiserum absorbed was precipitated three times with ammonium sulfate at $33 \%$ saturation to prepare rabbit $\mathrm{IgG}$ antibodies. The rabbit IgG antibodies were dialyzed against 0.01 $\mathrm{M}$ Tris- $\mathrm{HCl}$ buffer, $\mathrm{pH} 8.0$, containing $1 \% \mathrm{NaCl}$. The resulting antibodies will hereafter be called polyclonal antibodies. The reactivity and specificity of the polyclonal antibodies were assessed by an indirect immunoperoxidase reaction. In brief, the neutrophil surface proteins electrophoresed in $10 \%$ SDS-polyacrylamide gel were electrotransferred to a nitrocellulose paper in a buffer, $\mathrm{pH} 8.4$, composed of $25 \mathrm{mM}$ Tris, $192 \mathrm{mM}$ glycine, and $20 \%(\mathrm{v} / \mathrm{v})$ methanol (Western blotting). The nitrocellulose paper was then successively treated with the polyclonal antibodies to the surface membrane proteins, horseradish peroxidase-conjugated antirabbit IgG (Bio-Rad, Richmond, CA) and a colorant (Bio-Rad) for peroxidase reaction.

Neutrophil function tests. Adhesion of neutrophils onto a plastic Petri dish was tested by the method of Crowley et al. (3). Neutrophils adhered onto a glass coverslip were examined under a scanning electron microscope (JEOL, JSM-T 300) as described elsewhere (2). Chemotaxis was measured by the modified Boyden's-chamber method (19), using N-formyl-methionyl-leucylphenylalanine as a chemoattractant. Phagocytosis of Baker's yeast particles was measured by the method of Miller and Nilsson (20).

Monoclonal antibodies. Ascites containing monoclonal antibodies to Mac- $1 \alpha$, LFA- $1 \alpha$, and the $\beta$-subunit were kindly provided by Dr. T. Springer, Boston, MA, through the advice of Dr. D. Anderson, Houston, TX.

Radiolabeling and immunoprecipitation studies of neutrophil surface proteins. Neutrophils were surface-labeled with ${ }^{125} \mathrm{I}$ using Iodogen by the method of Fraker and Speck (21). Briefly, 1.2 $\mu \mathrm{g}$ of Iodogen in $30 \mu \mathrm{l}$ of dichloromethane was dried at room temperature for $20 \mathrm{~min}$ in the bottom of a small polypropylene tube. Then $2 \times 10^{6}$ diisopropylfluorophosphate-treated neutrophils in $10 \mu \mathrm{l}$ PBS and $120 \mu \mathrm{Ci}$ of ${ }^{125} \mathrm{I}$ (Amersham International, Buckingham, England) were added to the tube and incubated with gentle stirring at room temperature for $10 \mathrm{~min}$. After the incubation, the labeled neutrophils were transferred to another polypropylene tube that contained $3 \times 10^{6}$ neutrophils in $500 \mu \mathrm{l}$ PBS to stop the iodination. The neutrophils were then washed twice with PBS and solubilized in $0.5 \%$ Nonidet P-40 to extract the membrane proteins (6). Of the membrane protein extract thus prepared, $10 \mu \mathrm{l}$ were mixed with $20 \mu \mathrm{l}$ of $32 \mathrm{mg} / \mathrm{ml}$ polyclonal antibodies, or $20 \mu \mathrm{l}$ of $1: 100$ ascites containing monoclonal antibody to the $\beta$-subunit. The mixture was incubated at $4^{\circ} \mathrm{C}$ for $1 \mathrm{~h}$. The immune-complexes formed were precipitated by Staphylococcus aureus (Cowan I) (22), boiled in $20 \mu \mathrm{l}$ of Laemmli's sample buffer (16), and electrophoresed in a $7.5 \%$ polyacrylamide slab gel with SDS. After electrophoresis, the gel was dried and subjected to autoradiography using Fuji RX x-ray film and enhancing screens (Fuji Hi Screen P, Tokyo, Japan).

Immunofluorescence flow cytometry. Neutrophil suspensions, $5 \times 10^{6}$ cells in $50 \mu \mathrm{l}$ PBS per assay, were mixed with $5 \mu$ lascitic fluid containing one of the three monoclonal antibodies. The mixtures were left at room temperature for $1 \mathrm{~h}$, washed twice with cold PBS, and incubated for $1 \mathrm{~h}$ with $100 \mu \mathrm{l}$ of FITC-

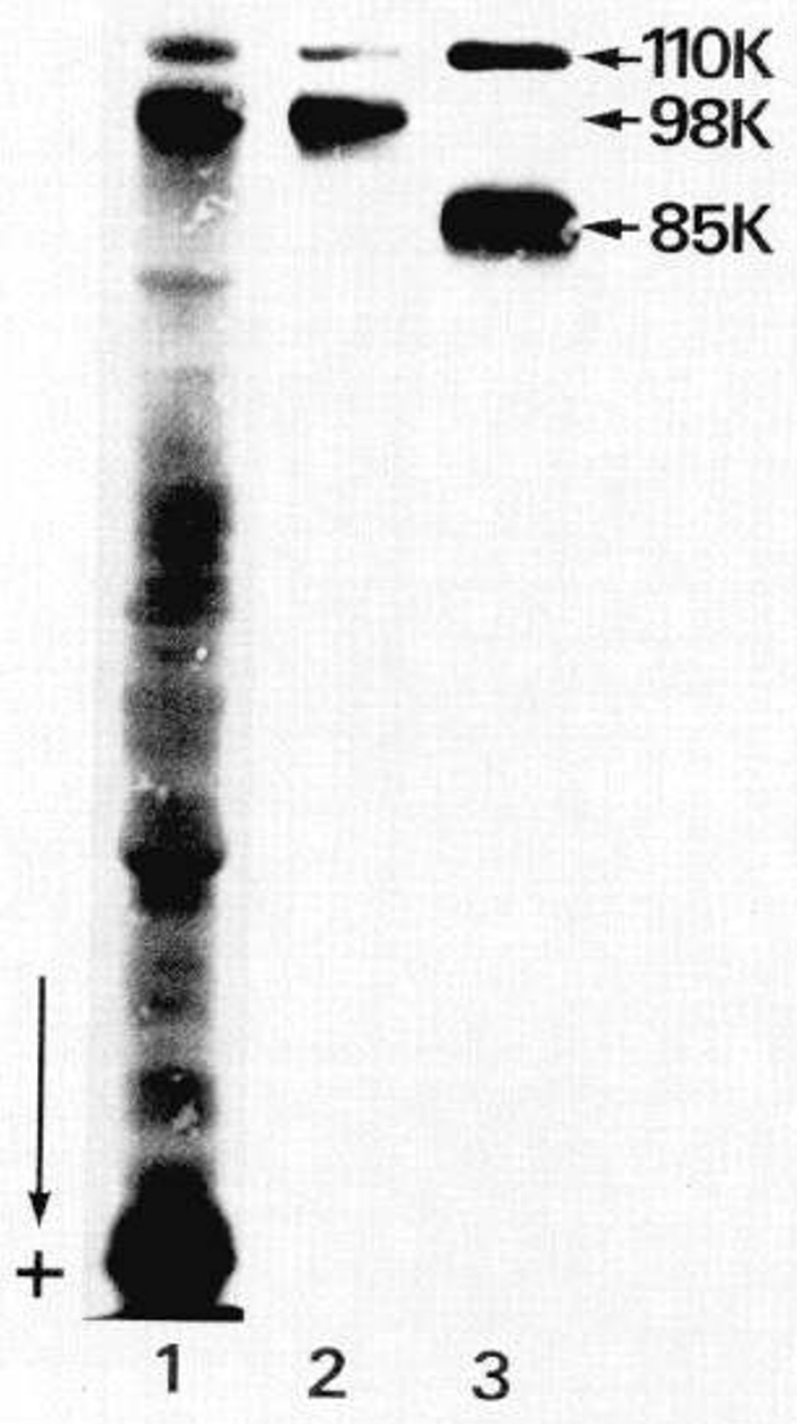

Fig. 1. Western blotting of protein bands separated on SDS-PAGE of surface membrane proteins of neutrophils from normal individuals, followed by an indirect immunoperoxidase reaction. Lane 1 , reacted with a rabbit antiserum against neutrophil surface membrane proteins rich in gp 110 of normal individuals. Lane 2, reacted with the antibodies absorbed by the siblings' neutrophil surface proteins. Two bands, one at $110 \mathrm{~K}$ and the other at $98 \mathrm{~K}$, are visible. Lane 3, same as lane 2 except that the neutrophil proteins were reduced with $\beta$-mercaptoethanol before SDS-PAGE. The $98 \mathrm{~K}$ band was replaced by an $85 \mathrm{~K}$ band. 
conjugated rabbit- $\mathrm{F}\left(\mathrm{ab}^{\prime}\right)_{2}$ antimouse $\mathrm{IgG}$ at a $1: 10$ dilution in PBS containing $2 \%$ heat-inactivated normal rat serum (23). The neutrophils thus treated were then washed with PBS, and run through a fluorescence-activated cell sorter (FACS III, Becton Dickinson, FACS Systems, Sunnyvale, CA).

\section{RESULTS}

Characterization of the rabbit polyclonal antibodies. Neutrophil membrane proteins from a normal individual, electrophoresed by SDS-PAGE, transferred to a nitrocellulose membrane, and reacted with the polyclonal antibodies, were stained with indirect peroxidase reaction. Two bands were observed: one with a molecular weight of $110 \mathrm{~K}$ and the other with an approximate molecular weight of $98 \mathrm{~K}$ (Fig. 1, lane 2). The reason for the absence of the $115 \mathrm{~K}$ band is unknown. It may be that the amount of the $115 \mathrm{~K}$ glycoprotein (gp 115) in the gel block used in producing the polyclonal antibodies was too small. The $98 \mathrm{~K}$ protein (p 98), when treated with $\beta$-mercaptoethanol, converted to a protein with a molecular weight of approximately $85 \mathrm{~K}$, while the $110 \mathrm{~K}$ protein ( $\mathrm{gp} \mathrm{110)}$ remained unchanged after the treatment (Fig. 1, lane 3). The polyclonal antibodies, reactive with both gp 110 and p 98, did not react with the siblings' neutrophil surface proteins, a finding indicating that both gp 110 and $\mathrm{p} 98$ were totally deficient in the siblings' neutrophils (Fig. 2). The amounts of the two surface proteins in the neutrophils of the siblings' parents were reduced, showing a low intensity in the two bands (Fig. 2).

The reactivity of the polyclonal antibodies was also tested with the surface proteins of normal lymphocytes solubilized with Nonidet P-40. As shown in Figure 3, the antibodies were reactive with a lymphocyte membrane protein of approximately $95 \mathrm{~K}$ daltons. This membrane protein was deficient in the siblings' lymphocytes (Fig. 3 right, lanes 2 and 3).

Effects of the polyclonal antibodies on the functions of normal neutrophils. Neutrophils from a normal woman were mixed with the polyclonal antibodies at a concentration of $100 \mu \mathrm{g}$ antibodies/ $0.5 \times 10^{6}$ neutrophils/ml PBS, set on a plastic dish, and examined for their mode of adhesion under a phase contrast microscope. Most of the neutrophils remained spherical with the polyclonal antibodies (Fig. 4a), while those with a normal rabbit IgG at the same concentration used for a control experiment showed spreading onto the plastic surface (Fig. $4 b$ ). Under a scanning electron microscope, neutrophils adhered on a glass coverslip revealed few pseudopods when tested with the polyclonal antibodies (75 $\mu \mathrm{g}$ of antibodies/0.5 $\times 10^{6}$ neutrophils/40 $\mu \mathrm{l}$ PBS) (Fig. $4 c$ ), while those with the normal rabbit $\operatorname{IgG}$ at the same concentration showed spreading and many pseudopods (Fig. 4d).

Function tests were carried out for normal neutrophils combined with increasing amounts of the polyclonal antibodies. Control experiments were performed using the normal rabbit IgG. In both experiments, neutrophils from a normal man and woman were used, and their mean values were plotted in Figure 5. The rate of adhesion (anchoring) decreased when larger amounts of the antibodies were added (Fig. 5, top). Almost complete inhibition of adhesion was achieved at an antibody concentration of $100 \mu \mathrm{g} / 0.5 \times 10^{6}$ neutrophils/ml PBS, while there was no noticeable decrease in the normal rabbit IgG. During these experiments, no aggregation of neutrophils was noted at the concentrations of the polyclonal antibodies used. The normal neutrophils treated with the polyclonal antibodies showed decreasing chemotaxis with increasing antibody concentration, although they were not affected by the normal rabbit IgG (Fig. 5, middle). Phagocytosis was also inhibited when larger

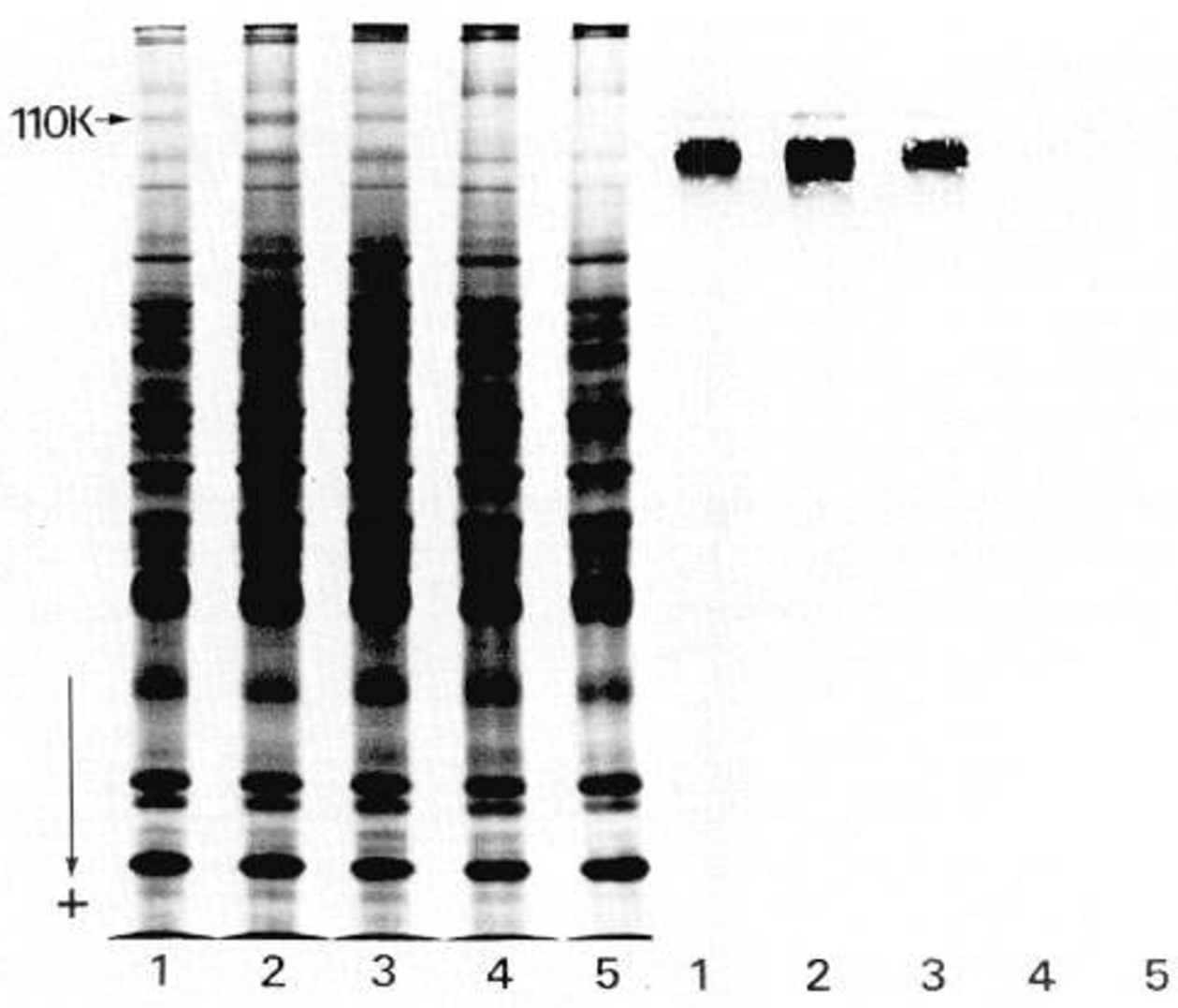

Fig. 2. Left, SDS-PAGE of neutrophil surface proteins stained by Coomassie Brilliant Blue. The arrow indicates the $110 \mathrm{~K}$ band. Lane 1 , the sibling's father with a reduced $110 \mathrm{~K}$ band. Lane 2, a normal adult. Lane 3, the siblings' mother with a reduced $110 \mathrm{~K}$ band. Lanes 4 and 5 , the brother and sister with a missing $110 \mathrm{~K}$ band. Right, indirect immunoperoxidase reaction with the antibodies absorbed by the siblings' neutrophil surface proteins. Both the $110 \mathrm{~K}$ and $98 \mathrm{~K}$ bands are reduced in the parents and missing in the siblings. 


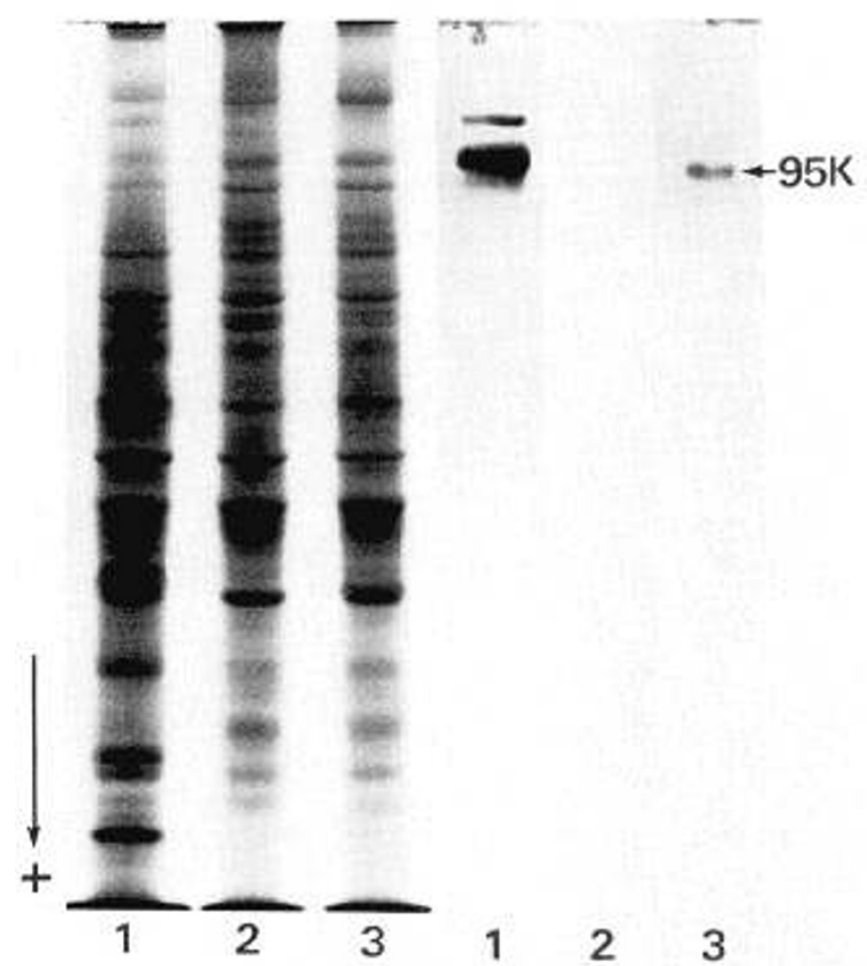

Fig. 3. Left, SDS-PAGE of proteins. Lane I, neutrophil surface membrane proteins from a normal adult. Lane 2, lymphocyte surface proteins from the siblings. Lane 3, lymphocyte surface proteins from a normal adult. Right, indirect immunoperoxidase reaction with the absorbed amounts of the polyclonal antibodies were added (Fig. 5, bottom). An inhibitory effect of a lesser degree was also noted with the normal rabbit IgG.

The inhibitory effect of the polyclonal antibodies was most apparent on the adhesion of the normal neutrophils, less apparent on chemotaxis, and much less on phagocytosis.

Comparison of polyclonal antibodies with anti- $\beta$-subunit monoclonal antibody. The polyclonal antibodies and the anti- $\beta$-subunit antibody were compared using immunoprecipitation with normal neutrophil membrane proteins, followed by SDS-PAGE and autoradiography. The labeling band patterns with both systems were identical, each consisting of three bands. It was assumed that the bands represented two of the three $\alpha$-subunits of the Mac- 1 family proteins and the $\beta$-subunit, the latter band being broad and abundant, situated to the anodal side from the $\alpha$ subunit bands (data not shown).

Analysis of neutrophil membrane proteins by flow cytometry. Neutrophils from the siblings as well as those from a normal adult were analyzed with indirect immunofluorescence flow cytometry using monoclonal antibodies to Mac- $1 \alpha, \mathrm{LFA}-1 \alpha$, or the $\beta$-subunit. The neutrophils from the normal adult were fluorescence positive with all the monoclonal antibodies tested, while the neutrophils from the siblings were fluorescence negative with each of the antibodies tested, and thus were deficient in Mac- $1 \alpha$, LFA- $1 \alpha$, and the $\beta$-subunit (data not shown). This in turn indicated that their neutrophils were deficient in Mac-1, LFA-1, and probably in p 150,95 . While the monoclonal antibody to $\mathrm{p} 150,95 \alpha$ was unavailable to us, it was deduced that $\mathrm{p} 150,95$

antibodies. The $95 \mathrm{~K}$ band is absent in lymphocyte surface proteins of the siblings (lane 2) but present in lymphocyte surface proteins of the normal adult (lane 3 ).
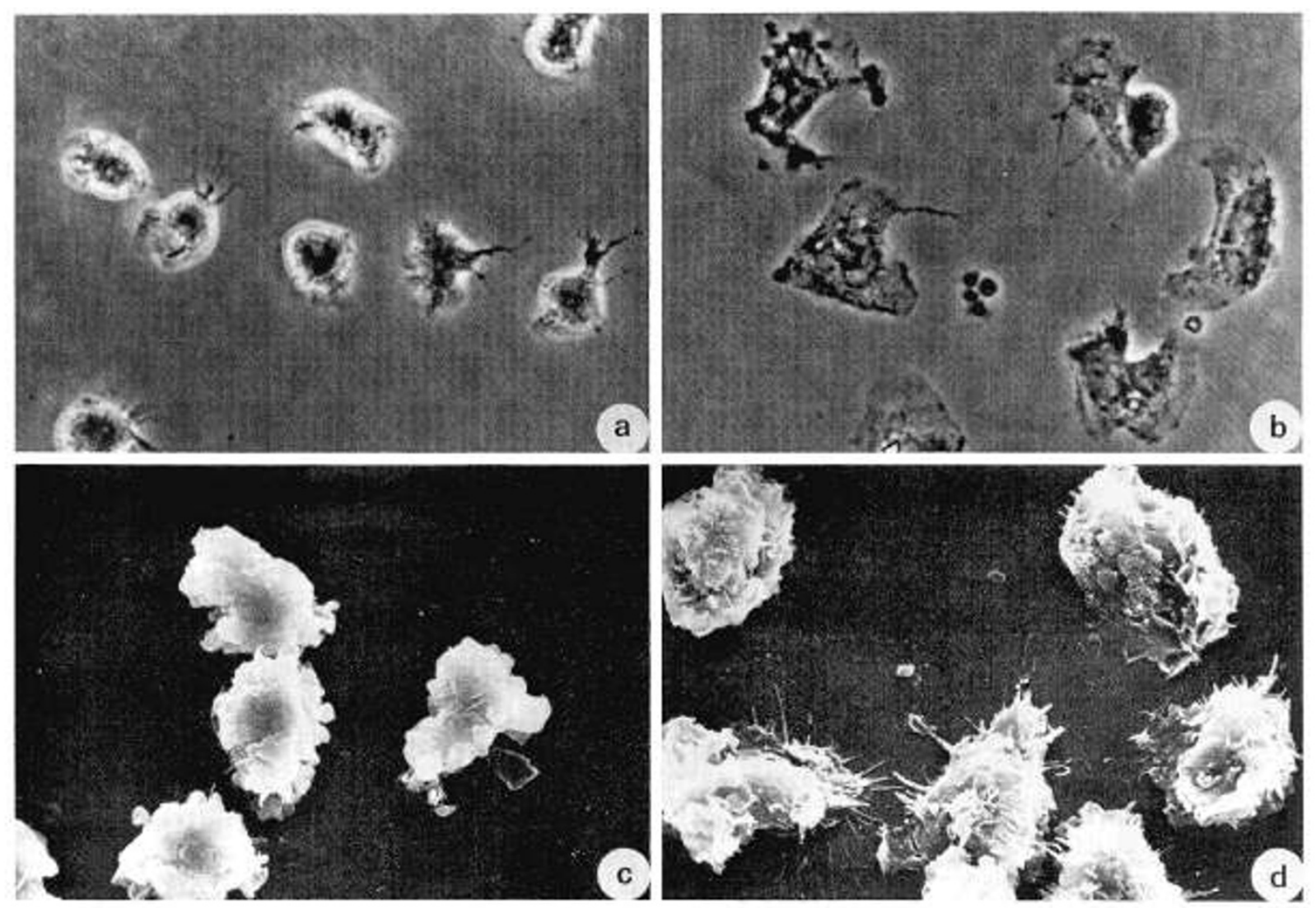

Fig. 4. a, phase contrast microscopy of spherical neutrophils from a normal individual on a plastic surface in the presence of the $\mathrm{IgG}$ antibodies. $b$, the same as a except a normal rabbit $\operatorname{IgG}$ was used in place of the $\operatorname{IgG}$ antibodies. The neutrophils are spread onto the plastic surface. $c$, scanning electron microscopy of neutrophils from the normal individual treated by the IgG antibodies. The cells are shrunk with few pseudopods. $d$, the same as $c$ except that normal rabbit IgG was used in place of the $\operatorname{IgG}$ antibodies. The neutrophils assume a normal shape with many pseudopods. 


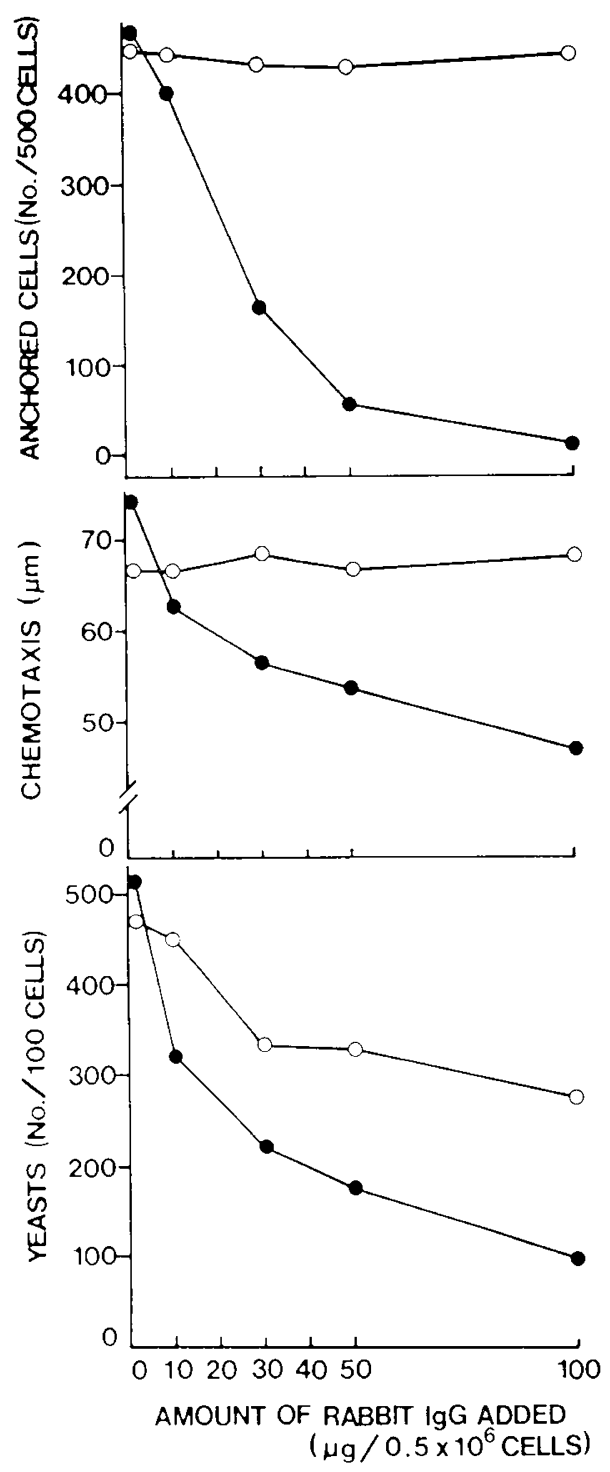

Fig. 5. The effect of the $\operatorname{IgG}$ antibodies on adhesion (top), chemotaxis (middle), and phagocytosis (bottom) of normal neutrophils. Neutrophils treated by the $\operatorname{IgG}$ antibodies ( ) and those treated by normal rabbit IgG $(O)$. The results are the mean values obtained from studying two normal adults, a man and woman.

was also deficient in the neutrophils of the siblings, because p150,95 contains the $\beta$-subunit as a component.

\section{DISCUSSION}

As mentioned earlier, at least 13 individuals from 11 families, including our sister and brother, have recently been described with a neutrophil adhesion disorder $(1-12)$, most likely inherited in an autosomal recessive fashion $(1,12)$. The use of SDS-PAGE for studies of leukocyte surface glycoproteins deficient in these patients has contributed to considerable confusion concerning the identity of the disease. A wide range of molecular weight determinations have been assigned to the deficient glycoproteins, employing a variety of gel conditions.

The introduction of monoclonal antibodies to leukocyte surface glycoproteins clarified the confusion and ascertained that at least six of the 13 individuals suffer from an identical disease $(9$, 12). The antibodies used included those to three cell surface glycoproteins related to each other, i.e. Mac-1, LFA-1, and p150,95. Mac-1, originally found on murine macrophages, was later shown to cross-react with monoclonal antibodies directed at human neutrophil or monocyte glycoproteins, and is now known to represent the $\mathrm{C} 3 \mathrm{bi}$ receptor of human myeloid cells (24-26). Each of the three Mac-1 family glycoproteins consists of an $\alpha$-and $\beta$-subunit. The $\beta$-subunit, with a molecular weight of $95 \mathrm{~K}$, is common to them, whereas their $\alpha$ subunits are different from each other, with a molecular weight of $165 \mathrm{~K}$ for Mac- $1 \alpha, 177 \mathrm{~K}$ for LFA- $1 \alpha$, and $150 \mathrm{~K}$ for p150,95 $\alpha$ (27). Our flow cytometric analysis using monoclonal antibodies to Mac$1 \alpha$, LFA- $1 \alpha$, and the $\beta$-subunit disclosed that the neutrophils of our siblings lack all these subunits, and thus lack Mac-1, LFA-1 and probably also p150,95. It is thus certain that the neutrophil abnormality in our siblings is identical with that identified by Anderson et al. (9) and Springer et al. (12). Our polyclonal antibodies behaved in the similar manner as the monoclonal anti- $\beta$-subunit antibody on SDS-PAGE following the immunoprecipitation procedure, an indication that the polyclonal antibody at least reacted with the $\beta$-subunit of the Mac-1 family glycoproteins.

As mentioned earlier, three membrane proteins were deficient in the neutrophils of our siblings: gp 110 and gp 115 identified in previous studies $(1,2)$ and $\mathrm{p} 98$ ascertained in this study. P 98 was judged as the $\beta$-subunit of the Mac- 1 family based on its mobility on SDS-PAGE of immunoprecipitates formed by the polyclonal antibodies and by the anti $\beta$-subunit antibody. The deficiency of $\mathrm{p} 98$ on the neutrophils of our siblings was proven by an indirect immunoperoxidase reaction using the polyclonal antibodies. Its deficiency could not be identified on conventional SDS-PAGE, superimposed by a glycoprotein with the same electrophoretic mobility. Thus, it s not certain whether p 98 is a glycoprotein, although it is likely to be so. P95, found deficient in this study in the lymphocytes of our siblings, is likely to be the $\beta$-subunit of LFA- 1 , in view of the fact that of the Mac-1 family surface proteins only LFA- 1 is present on the surface of the lymphocytes (28). According to Springer et al. (12) the $\beta$ subunits of Mac-1, LFA-1, and p150,95 were identical in molecular weight, $95 \mathrm{~K}$ daltons. However, in our experiment, the molecular weight of the $\beta$-subunit in lymphocytes ( $95 \mathrm{~K}$ daltons) was consistently different from that of the $\beta$-subunit in neutrophils (98 K daltons) as shown in Figure 3. It is thus likely that the $\beta$-subunit in lymphocytes is different from that in neutrophils in carbohydrate content. Further study is necessary to prove this assumption.

Gp 110 and gp 115 are likely to represent two of the three $\alpha$ subunits of Mac-1, LFA-1, and p150,95, but their precise identification awaits further studies.

$\mathrm{P} 98$, the $\beta$-subunit, when reduced with $\beta$-mercaptoethanol converted to a protein with a molecular weight of $85 \mathrm{~K}$, while gp 110 remained unchanged when given the same treatment. A possible explanation for this phenomenon is that the molecular configuration of $\mathrm{p} 98$ was altered through cleavage caused by a reduction of the intrachain disulfide bonds, thus rendering the protein more mobile on SDS-PAGE. Alternatively, p 98 may have been separated through the treatment into several subunits, one with a molecular weight of $85 \mathrm{~K}$ and the others with smaller molecular weights, the latter of which are assumed to be nonreactive with the antibodies used in the study.

The effect of the polyclonal antibodies on the function of neutrophils from normal individuals is worthy of comment. The inhibitory effect of the antibodies was most marked on the adhesion of neutrophils as observed by both phase contrast microscopy and electron microscopy, less marked on chemotaxis, and much less on phagocytosis. This was somewhat different from the behavior of the siblings' neutrophils, of which adhesion, chemotaxis, and phagocytosis were severely impaired. The difference may have reflected that of the neutrophil membrane proteins affected: the polyclonal antibodies are assumed to affect an $\alpha$-subunit and the $\beta$-subunit, while the siblings' neutrophils most likely lacked all three Mac-1 family membrane proteins.

Further studies of neutrophil adhesion defects and their defi- 
cient membrane proteins will facilitate the understanding of various functions of the neutrophils.

Acknowledgments. The authors are indebted to Dr. T. Springer for providing us with monoclonal antibodies to Mac- $1 \alpha$, LFA$1 \alpha$, and the common $\beta$-subunit, to Dr. D. Anderson for his valuable suggestions and allowing us the access to an unpublished paper, to Dr. S. Tomonaga for his advice on scanning electron micrography, and to Dr. T. Fukumoto for his advice on immunofluorescence flow cytometry.

\section{REFERENCES}

1. Kobayashi K, Fujita K, Okino F, Kajii T 1984 An abnormality of neutrophil adhesion: autosomal recessive inheritance associated with missing neutrophil glycoproteins. Pediatrics 73:606-610

2. Fujita K, Kobayashi K, Kajii T 1985 Impaired neutrophil adhesion: a new patient in a previously reported family. Acta Paediatr Jpn 27:527-534

3. Crowley CA, Curnutte JT, Rosin RE, Schwartz JA, Gallin JI, Klempner M, Snyderman R, Southwick FS, Stossel TP, Babior BM 1980 An inherited abnormality of neutrophil adhesion. N Engl J Med 302:1163-1168

4. Abramson JS, Mills EL, Sawyer MK, Regelmann WR, Nelson JD, Quie PG 1981 Recurrent infections and delayed separation of the umbilical cord in an infant with abnormal phagocytic cell locomotion and oxidative response during particle phagocytosis. J Pediatr 99:887-894

5. Bowen TJ, Ochs HD, Altman LC, Price TH, Van Epps DE, Brautigan DL Rosin RE, Perkins WD, Babior BM, Klebanoff SJ, Wedgwood RJ 1982 Severe recurrent bacterial infections associated with defective adherence and chemotaxis in two patients with neutrophils deficient in a cell-associated glycoprotein. J Pediatr 101:932-940

6. Arnaout MA, Ditt J, Cohen HJ, Melamed J, Rosen FS, Colten HR 1982 Deficiency of a granulocyte-membrane glycoprotein (gp 150) in a boy with recurrent bacterial infections. $N$ Engl J Med 306:693-699

7. Fischer A, Trung PH, Descamps-Latscha B, Lisowska-Grospiérre B, Gerota I Perez N, Sheinmetzler C, Durandy A, Virelizier JL, Griscelli C 1983 Bone marrow transplantation for inborn error of phagocytic cells associated with defective adherence, chemotaxis, and oxidative response duing opsonized particle phagocytosis. Lancet 2:473-476

8. Dana N, Todd III RF, Pitt J, Spinger TA, Arnaout MA 1984 Deficiency of a surface membrane glycoprotein (Mol) in man. J Clin Invest 73:153-159

9. Anderson DC, Schmalstieg FC, Arnaout MA, Kohl S, Tosi MF, Dana N Buffone GJ, Hughes BJ, Brinkley BR, Dickey WD, Abramson JS, Springer T, Boxer LA, Hollers JM, Smith CW 1984 Abnormalities of polymorphonuclear leukocyte function associated with a heritable deficiency of high molecular weight surface glycoproteins (GP 138): common relationship to diminished cell adherence. J Clin Invest 74:536-551

10. Beatty PG, Ochs HD, Harlan JM, Price TH, Rosen H, Taylor RF, Hansen JA, Klcbanoff SJ 1984 Absence of monoclonal-antibody-defined protein complex in boy with abnormal leukocyte function. Lancet 1:535-537

11. Kohl S, Springer TA, Schmalstieg FS, Loo LS, Anderson DC 1984 Defective natural killer cytotoxicity and polymorphonuclear leukocyte antibody-de- pendent cellular cytotoxicity in patients with LFA-1/OKM-1 deficiency. J Immunol 133:2972-2978

12. Springer TA, Thompson WS, Miller LJ, Schmalstieg FC, Anderson DC 1984 Inherited deficiency of the Mac-1, LFA-1, p150,95 glycoprotein family and its molecular basis. J Exp Med 160:1901-1918

13. Fan PT, Yu DTY, Pearson CM, Bluestone R 1977 Human monocyte-lymphocyte interaction: a new technique. J Immunol 119:156-161

14. Böyum A 1968 Isolation of mononuclear cells and granulocytes from human blood; isolation of mononuclear cells by one centrifugation, and of granulocytes by combining centrifugation and sedimentation at $1 \mathrm{~g}$. Scand $\mathrm{J}$ Clin Lab Invest [Suppl] 97:77-89

15. Mishell BB, Shiigi SM, Henry C, Chan EL, North J, Gallily R, Slomich M Miller K, Marbrook J, Parks D, Good AH 1980 Preparation of mouse cell suspensions. In: Mishell BB, Shiigi SM (eds) Selected Methods in Cellular Immunology. WH Freeman, San Francisco, pp 3-27

16. Laemmli UK 1970 Cleavage of structural proteins during the assembly of the head of bacteriophage T4. Nature 227:680-685

17. Goudie RB, Horne CHW, Wilkinson PC 1966 A simple method for producing antibody specific to a single selected diffusible antigen. Lancet 2: 1224-1226

18. Kobayashi K, Hirai H 1980 Studies of subunit components on chicken polymeric immunoglobulins. J Immunol 124:1695-1704

19. Baum J, Mowat AG, Kirk JA 1971 A simplified method for the measurement of chemotaxis of polymorphonuclear leukocytes from human blood. J Lab Clin Med 77:501-509

20. Miller ME, Nilsson UR 1970 A familial deficiency of the phagocytosisenhancing activity of serum related to a dysfunction of the fifth component of complement (C5). N Engl J Med 282:354-358

21. Fraker PJ, Speck JC Jr 1978 Protein and cell membrane iodination with a sparingly soluble chloroamide, 1,3,4,6-tetrachloro-3a,6a-diphenylglycol uril. Bioch Biophys Res Commun 80:849-857

22. Kessler SW 1975 Rapid isolation of antigens from cells with a staphylococcal protein A-antibody absorbent: parameters of the interaction of antibodyantigen complexes with protein-A. J Immunol 115:1617-1624

23. Fukumoto T, Kimura $H$, Naito $M$, Miyamoto $M$, Yamashita A, Sugiyama $H$ 1984 Monoclonal antibodies to rat liver cell membrane glycoproteins. Mol Immunol 21:285-291

24. Springer T, Galfre G, Secher DS, Milstein C 1979 Mac-1: a macrophage differentiation antigen identified by monoclonal antibody. Eur $\mathrm{J}$ Immunol 9:301-306

25. Ault KA, Springer TA 1981 Cross reaction of a rat-anti-mouse phagocytespecific monoclonal antibody (anti-Mac-1) with human monocytes and natural killer cells. J Immunol 126:359-364

26. Beller DI, Springer TA, Schreiber RD 1982 Anti-Mac-1 selectively inhibits the mouse and human type three complement receptor. J Exp Med 156:10001009

27. Sanchez-Madrid F, Nagy JA, Robbins E, Simon P, Springer TA 1983 A human leukocyte differentiation antigen family with distinct $\alpha$-subunits and a common $\beta$-subunit: The lymphocyte function-associated antigen (LFA-1), the C3bi complement receptor (OKMI/Mac-1), and the p150,95 molecule. J Exp Med 158:1785-1803

28. Krensky AM, Sanchez-Madrid F, Robbins E, Nagy JA, Springer TA, Burakoff SJ 1983 The functional significance, distribution, and structure of LFA-1, LFA-2, and LFA-3: cell surface antigens associated with CTL-target interactions. J Immunol 131:611-616 